Regards sur l'économie allemande

Bulletin économique du CIRAC

$75 \mid 2006$

Varia

\title{
Politique familiale
}

Starke Familie. Bericht der Kommission « Familie und demographischer Wandel »

\section{(2) OpenEdition}

\section{Journals}

Édition électronique

URL : http://journals.openedition.org/rea/501

DOI : $10.4000 /$ rea. 501

ISBN : 978-2-8218-0846-1

ISSN : 1965-0787

Éditeur

CIRAC

Édition imprimée

Date de publication : 1 mars 2006

ISSN : 1156-8992

Référence électronique

"Politique familiale », Regards sur l'économie allemande [En ligne], 75 | mars 2006, document 9, mis en ligne le 24 avril 2008, consulté le 22 septembre 2020. URL : http://journals.openedition.org/rea/501 ; DOI : https://doi.org/10.4000/rea.501

Ce document a été généré automatiquement le 22 septembre 2020

(C) CIRAC 


\section{Politique familiale}

Starke Familie. Bericht der Kommission « Familie und demographischer Wandel »

\section{RÉFÉRENCE}

Starke Familie. Bericht der Kommission « Familie und demographischer Wandel » , Robert Bosch Stiftung, Stuttgart, 2005, 120p.

1 Voilà le rapport sur la politique familiale face au défi démographique, tel qu'il a été rédigé par la Commission Biedenkopf instituée par la Fondation Robert Bosch en 2004. Constatant que c'est principalement le régime d'assurance vieillesse qui se révèle désincitatif, elle préconise quatre mesures pour relancer la natalité : développer les prestations familiales; réduire la part de la redistribution dans le système de prévoyance (surtout en matière de retraites, où elle pénalise les familles) ; accroître la capitalisation retraite pour les couples sans enfants; plus généralement, ces changements, mais aussi des mesures fiscales, sont de nature à amorcer un changement culturel basé sur la valorisation de la famille. (ib) 